\title{
The Determinants of Dividend Policy: A Study of Financial Industry in Indonesia
}

\author{
Gusni \\ Department of Management, Faculty of Business and Management University of Widyatama \\ Jl. Cikutra No.204A Bandung, 40125, Indonesia
}

\begin{abstract}
Keywords: Corporate Governance Mechanism; Dividend policy is still a controversial issue and often debated in the literature of corporate finance. Previous literature has examine that companies pay dividend is to attract Dividend Policy; Firm Size; Leverage; Profitability; Systematic Risk investors to buy their companies shares. The question, what are the determinants of the company's dividend policy? The purpose of this study is to find out the determinants of dividend policy in financial industry listed in Indonesia Stock Exchange. This study use a panel data analysis method to investigate the determinants of dividend policy (corporate governance mechanism, profitability, systematic risk, firm size, and leverage) in Indonesia Stock Exchange which sample were taken from 17 companies by using purpoJEL Classification: G35, G34 sive sampling technique from the period of 2009-2015. The empirical result shows that profitability, leverage, and institutional ownership have negative impact on the firm's dividend policy. This study revealed that systematic risk, firm size, and board of directors have no impact to the firm's dividend policy.

\section{ABSTRAK}

Kata Kunci: Mekanisme Corporate Governance; Kebijakan Dividen; Ukuran Perusahaan; Leverage; Profitabilitas; Risiko Sistematik

Kebijakan dividen masih menjadi isu kontroversial dan sering diperdebatkan dalam literatur keuangan perusahaan. Literatur sebelumnya telah menjelaskan bahwa perusahaan membayar dividen adalah untuk menarik minat investor terhadap saham perusahaan mereka. Pertanyaannya adalah, apa faktor penentu kebijakan dividen perusahaan? Tujuan dari penelitian ini adalah untuk mengetahui faktor-faktor penentu kebijakan dividen di industri keuangan yang terdaftar di Bursa Efek Indonesia. Penelitian ini menggunakan metode analisis data panel untuk mengetahui faktor-faktor penentu kebijakan dividen (corporate governance mechanism, profitabilitas, risiko sistematis, ukuran perusahaan, dan leverage) di Bursa Efek Indonesia dengan sampel sebanyak 17 perusahaan yang dipilih dengan menggunakan teknik purposive sampling periode 2009-2015. Hasil uji empiris menunjukkan bahwa profitabilitas, leverage, dan kepemilikan institusi berpengaruh negatif terhadap kebijakan dividen perusahaan. Penelitian ini mengungkapkan bahwa risiko sistematis, ukuran perusahaan, dan dewan direksi tidak berpengaruh terhadap kebijakan dividen perusahaan.
\end{abstract}


Questions arise often regarding company dividend policies are, why some companies pay dividends and others do not? Since there has been shifting understanding of dividend policy from only thinking about how much cash dividends should be paid and how many payments will be made in a year to more varied decisions such as whether cash will be distributed through share repurchases or cash dividends, accentuate rising stock prices by hold more earnings or distributing larger dividends, and how to keep stability between individual investor interests with higher dividend taxes than institutional investors with lower dividend taxes, this question remain unresolved in the corporate finance literature. A number of theories have been recommended to explain firm dividend behavior, like agency cost model and dividend signaling model. However, both of theories cannot fully answer the question, although agency cost model emphasizes the function of dividend payments is to reduce agency problems between managers and shareholders, and dividend signaling accentuate that dividend needed to provide positive information about the company's condition to the investors (Arifin, 2007). The explanation of the company's dividend policy behavior remains unclear until now. Elucidation on the determinant of the firm's dividend policy is limited. That is why dividend policy is like puzzle as state by Denis \& Osobov (2008), and still calling for further empirical research.

The objective of this paper is re-examine determinants of firm's dividend policy in the financial industry by following the theoretical and previous empirical research that can contribute to dividend debate in the world and improve our understanding about firm's dividend policy. Even though a number of studies have tried to explain the determinants of dividend policy, but the results are still controversial without definite solution. The financial industry is very interesting to investigate because its role in moving the wheels of the country's economy is very important. Financial industry firm's continuous to grow in Indonesia, but only a few companies pay dividend to the shareholders continuously. This paper will use a number of determinants dividend policy such as corporate governance mechanism, profitability, systematic risk, firm size, and leverage as used by Kowalewski et. al. (2007), Abdelsalam, El-Masry, \& Elsegini (2008), Denis \& Osobov (2008), Adjaoud \& Ben-Amar (2010), Moradi, Salehi, \& Honarmand (2010), Ahmad \& Wardani (2014), Vo \& Nguyen (2014), Aydin \& Cavdar (2015), Kajola, Desu, \& Agbanike (2015), Ahmed (2015); Elmi \& Muturi (2016), and Kulathunga, Weerasinghe, \& Jayarathne (2017), to predict firm dividend policy.

This research is conducted different from other studies. Firstly, this research uses financial listed firms In Indonesia. Using this firm inspired from study by Naceur, Goaied, \& Belanes (2006) that use regulated industries (financial, transport, and telecommunication firms) and unregulated industries in Tunisian Stock Exchange. They research only uses profitability, market to book value, ownership (number of majority shareholders holding more than 5 percent of stocks), leverage, size and market liquidity, and focus on current earning and previous dividend. Their research does not using corporate governance mechanism and systematic risk as determinants of dividend policy. Corporate governance practice still new in Indonesia, which is why important to analyze related to its function to protect the outsiders from any asset manipulation by the insiders companies. Systematic risk also important to analyze related to firm's business risk that still rarely studied in previous research. Secondly, this study uses the agency cost and dividend signaling model as main theory to explain determinants of dividend policy to provide a new look of what factors are determine dividend policies in the firm's financial industry listed in Indonesia Stock Exchange. 


\section{Jurnal Keuangan dan Perbankan | KEUANGAN}

Vol. 21, No. 4, Oktober 2017: 562-574

\section{HYPOTHESES DEVELOPMENT}

\section{Corporate Governance Mechanism and Firm Dividend Policy}

The corporate governance mechanism can be interpreted as mechanism, process, and correlation in which organizations are monitored and directed (Kulathunga, Weerasinghe, \& Jayarathne, 2017). Corporate governance is a system that regulates and controls companies to create value added for all stakeholders (Hidayati \& Sunaryo, 2016). Different parties has discussed corporate governance and become an imperative topic. According to agency theory, the various kind of corporate governance mechanism relies on the agency cost (Abor \& Fiador, 2013). In order to encourage managers to achieve the company's goal of maximizing shareholder wealth, a system of corporate governance is presented (Hutchinson \& Gul, 2004). This system has many benefits for companies, investors, and community generally. These benefits involve increasing company performance, reduction cost of capital, cover shareholders' rights by conformance to legal requirements, reinforce company reputation, diminish risk, and improve shareholder value (Coskun \& Sayilir, 2012). According to Shleifer \& Vishny (1997), the primary purpose of corporate governance mechanism is to make sure that shareholders' invest to the company and get a fair rate of return on their investment either through dividends and or capital gains (Aydin \& Cavdar, 2015). Dividend is really necessary shareholder right that can influence potential investors in making investment decision. The few empirical studies indicate an interaction between the dividend policy and governance structures derived from cross-country analysis in which some researcher tries to document that institutional and legal environment affect dividend policy. According to Adjaoud \& Ben-Amar (2010) and Jirapon et al. (2011), firms paying higher dividends are firms with strong corporate governance mechanism. Two of important corporate governance mecha- nism is the role of board of directors and institutional ownership.

\section{Board of Directors and Firm Dividend Policy}

John \& Senbet (1998), mention that board of directors has played important role in the company because they seen as main means to do control over top management for shareholders (Abor \& Fiador, 2013). In order to secure shareholder's value, the board of directors has a duty to set the whole company strategy and make sure that adequate controls are in place (Keenan, 2004). Board of directors has sum of obligation such as decide company financing, investment, and dividend decision. Vote to pay profit for shareholders as dividend is one of work manage by board to reduce agency cost and restrict management scope in making decision for owners (Belden, Fister, \& Knapp, 2005). This statement support by Adjaoud \& Ben-Amar (2010). they explain that company's dividend policy affected by board of directors. Research conducted by Abor \& Fiador (2013) and Roy (2015), also found that boards of directors affect the dividend policy. Based on the above explanation and theory, the first hypothesis can be formulated as follows:

$\mathrm{H}_{1}$ : the board of directors has a positive effect on the dividend policy

\section{Institutional Ownership and Dividend Policy}

Institutional ownership define as share own by investor institutional not individual. Institutional shareholders have important role in a company related to their ability to conduct supervision, gather information, and the impact on the company policies and performance (Yulianto, 2014). Large numbers of share from institutional shareholders will robust control of dividend payout decision (Gusni, 2016). Short, Zhang, \& Keasey (2002) investigate the relation between dividend policy and ownership structure in UK companies 
and found positive relation between institutional ownership and dividend payout. Mehrani, Moradi, \& Eskandar (2011), also examine there are positive relationship between institutional ownership concentrated with dividend payment in Tehran Stock Exchange for the period 2000-2007. Triwulan \& Wahidahwati (2012) and Saif et al. (2013) also found that institutional ownership has a positive and significant effect on the dividend policy. Refer to the above description and theory, the second hypothesis can be formulated as follows:

$\mathrm{H}_{2}$ : institutional ownership has a positive effect on the dividend policy

\section{Profitability and Firm Dividend Policy}

Company profitability has long been believed as the main key of firm's capacity to distribute dividend (Elmi \& Muturi, 2016). Mature and profitable companies tend to pay dividend, but companies that do not pay dividend are not firms that do not make a profit. Firms keep maintaining and increasing their dividend payment over time when they can manage their cash flow successfully (Ahmed, 2015). Denis \& Osobov (2008) state that companies in the US, Canada, Germany, and Japan tend to pay higher dividend between larger and more profitable firms. Fama \& French (2001), perform empirical analysis about weightiness of firm size, profitability, and growth opportunities in the company's decision to distribute dividend. This statement supports by Aivazian, Booth \& Cleary (2003) show that profitability influence company dividend policy. Pandey (2001) also analyze the dividend payout ratio behavior in Malaysia for the period of 1993-2000 and found that dividend policy influenced by profitability (Moradi, Salehi, \& Honarmand, 2010). Beabczuk (2004), explore the dividend policy in Argentina and found that big firms with a highest profit level without having a great investment opportunities keep to pay higher dividend, otherwise, firms with higher risk and loan will pay little dividends
(Moradi, Salehi, \& Honarmand, 2010). Kania (2005), Moradi, Salehi, \& Honarmand (2010), Chhaoti (2015), Kajola, Desu, \& Agbanike (2015), and BizaKhupe \& Themba (2016) also mention that firm's dividend policy affected by firm's profitability. Based on this mentioned information, the third hypothesis can be formulated as follows:

$\mathrm{H}_{3}$ : profitability has a positive effect on the dividend policy

\section{Systematic Risk and Firm Dividend Policy}

The disparity among actual return received by the investor and the expected return is called as a risk (Tendelilin, 2001). High levels of risk show that current and future benefits are less certain. Systematic risk measurement for stock or a portfolio relative to the market returns is beta as state by Jogianto (2009). Gitman (2009) mention that beta is a relative risk measurement of non diversifiable index of the return on asset movement in response changes in the market returns.

A historical return of assets can be used to find the asset beta coefficient. The higher of company systematic risk indicate the higher of the company's securities return sensitivity to market return change which may result lower company opportunity in getting an external source of funds, so that the company should be able to financing the company through internal sources. Consequently company will increase retained earnings and reducing the amount of the dividend. This indicates that higher of firm systematic risk will cause the lower of firm's dividend policy (Tendelilin, 2001). This statement support by Amidu \& Abor (2006), they said that systematic risk has a negative significant effect on the company's dividend policy in Ghana. Moradi, Salehi, \& Honarmand (2010) found an inverse relationship between systematic risk and corporate dividend policy in Iran. Adjaoud \& Ben-Amar (2010) also found that firm risk is negatively related to the firm's dividend payout policy in 
Canada. Cheryta et al. (2015) mention that systematic risk has a negative effect on the dividend policy in Indonesia. Refer to this information, the fourth hypothesis can be formulated as follows:

$\mathrm{H}_{4}$ : systematic risk has a negative effect on the dividend policy

\section{Firm Size and Firm Dividend Policy}

Firm size represents company capability to maximize firm profitability and dividend payment (Arifin, 2007). Generally, biggest firm better than smaller firm to hand out dividend to the shareholders due to have easier access to funding. Fama \& French (2001) mention that firm size is a determinant of corporate dividend policy (Ahmed, 2015). A number of empirical analysis indicate that firm size has a positive relationship with the company dividend policy like research conduct by Reddy \& Rath (2005), they found that company with large size paid the dividend in Indian. Adjaoud \& Ben-Amar (2010), Ahmad \& Wardani (2014), and Roy (2015), found the positive relationship between firm size and dividend policy. Based on this explanation, the fifth hypothesis can be formulated as follows:

$\mathrm{H}_{5}$ : firm size has a positive effect on the dividend policy

\section{Leverage and Firm Dividend Policy}

Leverage indicates how the companies finance their activities (Brigham \& Daves, 2004). A relationship between leverage and dividend distribution is expected from the trade-off theory state by Modigliani and Miller and pecking order theory proposed by Myers and Majluf (Trang, 2012). Modigliani \& Miller (1961) state that increase in debt level is a great signal for the company's prospect future and will increase the company value that will be impact to the firm willing in paying higher dividends. Debt will push the manager to enjoy fewer benefits and making the manager work more efficient for the company (Pujiastuti, 2008). Chang \& Rhee (1990) explain that higher leverage lead to lower tax rates, so it cause the firm able to pay higher dividend which mean there are positive relationship between leverage and firm dividend policy (Trang, 2012). According to Myers \& Bacon (2004), they found that leverage has positive association with dividend payout. Meanwhile, Afza \& Mirza (2010), Ahmad \& Wardani (2014), and Vo \& Nguyen (2014), argue that there is a negative relationship between leverage and dividend policy. Based on this mentioned information, the sixth hypothesis can be formulated as follows:

$\mathrm{H}_{6}$ : leverage has a negative effect on the dividend policy

\section{METHOD}

This research population is companies in the financial industry listed in Indonesia Stock Exchange for the period of 2009-2015 consist of 79 companies. The samples were taken from 17 companies by using a purposive sampling technique. The criteria used to select the sample were: (1) companies in financial industry listed in Indonesia Stock Exchange for the period 2009-2015; (2) companies paid dividends during the study period; (3) companies do not perform a stock split during the study period; and (4) the companies have the institutional ownership over the study period.

This study is explanatory research with a quantitative approach. The data used in this research was secondary data. Secondary data is data that is published or utilized by the other organization, not by the user. The data were gathered from the official website of Indonesia Stock Exchange (www.idx.co.id) and company annual report. For additional information, the researcher also takes information which has already existed, like articles, journals, text books, and etc. This research uses the combination of time series data 
and cross section data, known as pooling data/ panel data. Panel data give more informative data, more variability, less co-linearity among the variables, more degrees of freedom, and more efficiency (Zhao, 2013).

The variables observed in this research consist of dividend policy measure by using dividend payout ratio as dependent variable. CGM by us- ing board of directors (BOD) and institutional ownership (IO), profitability by using return on investment (ROI), systematic risk by using beta coefficient (beta), firm size (size) by using total asset, and leverage by using debt to asset ratio as independent variables. All the variables used in this research and measurements are shown in Table 1.

Table 1. Definition and Measurement of Operational Variables

\begin{tabular}{|c|c|c|c|}
\hline Variables & Proxy & Measurement & Reference \\
\hline $\begin{array}{l}\text { Board of Directors }\left(\mathrm{X}_{1}\right) \text { : the } \\
\text { company organ that has } \\
\text { responsibility to determine the } \\
\text { policies and strategies taken by } \\
\text { the company }\end{array}$ & Total board of directors & $\sum$ Board of directors & $\begin{array}{l}\text { Rachman, Rahayu, \& } \\
\text { Topowijono (2015); } \\
\text { Roy (2015) }\end{array}$ \\
\hline $\begin{array}{l}\text { Institutional Ownership }\left(\mathrm{X}_{2}\right) \text { : } \\
\text { share own by investor } \\
\text { institutional not individual }\end{array}$ & $\begin{array}{l}\text { Percentage of share owned } \\
\text { by institutional investor }\end{array}$ & $\begin{array}{l}\sum \text { Share owned by } \\
\text { investor institutional/ } \\
\sum \text { outstanding share }\end{array}$ & $\begin{array}{l}\text { Fadah (2010); Abor \& } \\
\text { Fiador (2013); Yulianto } \\
\text { (2014) }\end{array}$ \\
\hline $\begin{array}{l}\text { Profitability }\left(\mathrm{X}_{3}\right) \text { : company } \\
\text { ability to earn profit in certain } \\
\text { period. }\end{array}$ & Return on Investment & $\begin{array}{l}\text { Earnings after tax/ } \\
\text { total assets }\end{array}$ & $\begin{array}{l}\text { Brigham \& Daves } \\
(2004)\end{array}$ \\
\hline $\begin{array}{l}\text { Systematic Risk }\left(\mathrm{X}_{4}\right) \text { : a relative } \\
\text { risk measurement of non } \\
\text { diversifiable index of the return } \\
\text { on asset movement in response } \\
\text { changes in the market returns. }\end{array}$ & Stock Beta & $\beta_{\mathrm{i}}=\frac{\sigma_{\mathrm{i}, \mathrm{M}}}{\sigma^{2} \mathrm{M}}$ & $\begin{array}{l}\text { Gitman (2009); } \\
\text { Biza-Khupe \& Themba } \\
\text { (2016) }\end{array}$ \\
\hline $\begin{array}{l}\text { Firm Size }\left(X_{5}\right) \text { : indicate big or } \\
\text { small firm that can be expressed } \\
\text { in total assets, sales and market } \\
\text { capitalization. }\end{array}$ & Total Assets & $\sum$ Total Assets & $\begin{array}{l}\text { Ahmad \& Wardani } \\
\text { (2014); Biza-Khupe \& } \\
\text { Themba (2016) }\end{array}$ \\
\hline $\begin{array}{l}\text { Leverage }\left(X_{6}\right) \text { : indicates how the } \\
\text { companies finance their activities }\end{array}$ & Debt to Asset Ratio (DAR) & Total Debt/ Total Asset & $\begin{array}{l}\text { Brigham \& Daves } \\
\text { (2004); Ahmad \& } \\
\text { Wardani (2014) }\end{array}$ \\
\hline $\begin{array}{l}\text { Dividend Policy }(Y) \text { : is dividends } \\
\text { paid by the company are derived } \\
\text { from revenues or profits and } \\
\text { distributed in the form of cash } \\
\text { dividends and stock dividends to } \\
\text { the shareholders }\end{array}$ & $\begin{array}{l}\text { Dividend Payout Ratio } \\
\text { (DPR) }\end{array}$ & $\begin{array}{l}\text { Dividend per } \\
\text { share/earnings per } \\
\text { share }\end{array}$ & $\begin{array}{l}\text { Gitman (2009); Yuliani } \\
\text { et al. (2013) }\end{array}$ \\
\hline
\end{tabular}




\section{Jurnal Keuangan dan Perbankan | KEUANGAN}

Vol. 21, No. 4, Oktober 2017: 562-574

In the way to test the hypothesis proposed in this research used panel data regression model as used by Kajola, Desu, \& Agbanike (2015). The regression equation model is presented below:

$\mathrm{DPR}=\mathrm{a}+\beta 1 \mathrm{BOD}+\beta 2 \mathrm{IO}+\beta 3 \mathrm{ROI}+\beta 4 \mathrm{BETA}+$ $\beta 5$ SIZE $+\beta 6$ Leverage $+\mathrm{e}$

Where a was constant, $\beta 1, \beta 2, \beta 3, \beta 4, \beta 5, \beta 6$ were regression coefficients, and the variables already being defined in the Table 1 .

The primary step in conducting panel data regression model has conducted several classical assumption tests consist of normality, multicollinearity, autocorrelation, and heteroscedasticity test. The purpose of classical assumption test is to make sure that regression equation model has accuracy in estimation, unbiased, and consistent.

Test of the accuracy of the regression model in predicting the value of the dependent variable is determined by the goodness-of-fit. In measuring the goodness-of-fit, a panel data regression model can be analyzed through F-test. F-test is known as Anova test is used to find the relationship between independent variables and dependent variable or to test if the model used is fix or not (Lind, Marchal, \& Wathen, 2012). Furthermore, $\mathrm{R}^{2}$ test which is coefficient determination test to measure the ability of the independent variables used to define changes in the dependent variable. The last test is t-test or hypothesis test, used to analyze the impact of each independent variable individually toward the dependent variable or to answer the entire hypothesis proposed in this research.

\section{RESULTS}

The result of normality test using JarqueBera test show that Jarque-Bera probability value is $0.000>\alpha(\alpha=0.05)$, it can be said that the data are not normally distributed. But still can be used for further analysis refer to central limit theorem by McClave et al. (2013). Furthermore, multicollinearity test using correlation matrix for each independent variable resulted through the data processing shows that coefficient correlation are below 0.8 , which means there were no problems with multicollinearity in the model of the study. Autocorrelation test result using Durbin-Watson test shows that the value calculated is 2.3371 and Durbin-Watson table is $\mathrm{d}_{\mathrm{L}}=1.5966$ and $\mathrm{d}_{\mathrm{U}}=1.8079$, it is not showing a certain result because the Durbin-Watson value calculated is between $4-\mathrm{d}_{\mathrm{L}}$ and $4-\mathrm{d}_{\mathrm{U}}$. However, it can be concluded that there is no autocorrelation because the Durbin-Watson calculated is close to 2 .

The result of heteroscedasticity using the Breusch Pagan Godfrey (BPG) test resulted in $p$ value-obs*-square $0.5144>0.05$, which means there is no heteroscedasticity among the residuals in the regression model or the variance of the residuals keep staying the same across different observation or different values of independent variables.

The panel data regression results by using fixed effect model show the coefficient of independent variable, $t$-statistic, probability, coefficient of determination, and $\mathrm{F}$ test as shown in Table 2.

Table 2. Panel Data Regression Results

\begin{tabular}{lrrc}
\hline \multicolumn{1}{c}{ Variables } & Coefficient & t-Statistic & \multicolumn{1}{c}{ Prob. } \\
\hline BOD & -0.02132 & -0.27549 & 0.7835 \\
IO $^{* *}$ & -0.28140 & -2.08122 & 0.0401 \\
ROI $^{*}$ & -2.25079 & -3.57198 & 0.0006 \\
Beta & -0.00194 & -0.71757 & 0.4748 \\
Size & 0.00375 & 0.11765 & 0.9066 \\
Leverage* & -0.51046 & -2.87531 & 0.0050 \\
C & 0.87180 & 0.90827 & 0.3660 \\
\hline R-squared & 0.46042 & & \\
F-statistic & 5.57677 & & \\
Prob (F-statistic) & 0.00000 & & \\
\hline
\end{tabular}

*significant at the 0.01 level

** significant at the 0.05 level

Source: The processed data by using eviews 9

The regression analysis resulted showed that the coefficient of variation (b) which explains the direction of variability is negative for BOD, IO, 
ROI, Beta, and Leverage, which mean if BOD, IO, ROI, beta, and leverage increase in one unit, then DPR will decrease in the amount of coefficient of variation (b). Meanwhile size is positive, mean, if size increase in one unit, then DPR will increase in the amount of coefficient of variation (b) size.

F-test results show that independent variables used in this research are able to define dependent variable in a good way or the regression model is fixing.

The model developed for dividend policy is quite good, because the coefficient of determination $\left(\mathrm{R}^{2}\right)$ as shown in Table 2 is 0.4604 . It can be said that the variation in the dividend policy in the financial industry listed in Indonesia Stock Exchange can be explained by the variation in BOD, IO, ROI, beta, size, and leverage by 46.04 percent, taking into account the sample size and number of independent variables, while the remaining of 53.96 percent is explained by the variation of other variables outside of the regression model.

Hypothesis testing result indicate that institutional ownership (IO) and profitability have negative effect to the firms dividend policy, therefore the formulation of research hypotheses is rejected. Leverage also has negative effect to the company dividend policy, so that the formulation of research hypotheses is received. Meanwhile, board of directors (BOD), systematic risk (Beta), and firm size (Size) have no effect to the company dividend policy in the financial industry listed in Indonesia Stock Exchange. Therefore the formulation of research hypothesis is rejected.

\section{DISCUSSION}

Board of directors has played important role in the company and has responsibility to set up company strategy and control the process to protect shareholders interests. Another duty of the board of directors is vote to distribute profit earned by the company to the shareholders as dividend. Research result show that board of directors has no effect to the firm's dividend policy. Therefore this study confirms by Abdelsalam, ElMasry, \& Elsegini (2008) and Yulianto (2014), that found board size does not affect the dividend policy. This research indicate that board of directors commitment and responsibilities to increase shareholders wealth through increasing their control, policy, and strategy to gather more earning and distribute to the shareholder in the form of cash dividend not proven. Board o directors role still weak in perform shareholders duty to increase their wealth. This achievement is certainly less appreciated by the shareholders and contrary to the agency theory. Myers \& Bacon (2004) recommend that managers may attempt to avoid disciplinary action from shareholders with being willing to paid dividend. Normally, the shareholders prefer cash dividends and they tend to appreciate board of directors who pay dividends on a regular basis as suggested by Black (1976). This finding contrary with the study resulted by Adjaoud \& Ben-Amar (2010), Abor \& Fiador (2013), and Roy (2015), they mentioned that the boards of directors affect the dividend policy.

Institutional ownership is share own by investor institutional not individual. Investor institutional believed as a monitoring device on the firm's managers. Institutional ownership has an important role in the corporate governance, especially related to their ability to supervise, obtain information, and impact on company policies and performance. Institutional shareholders with a large number of shares have a stronger control related to the dividend payout policy. This study indicates that institutional ownership has negative effect to the dividend policy. This research finding in line with research conducted by Kouki \& Guizani (2009) and Thanatawee (2014), they state that there is a significant negative effect of institutional ownership on the dividend policy. The nega- 


\section{Jurnal Keuangan dan Perbankan | KEUANGAN}

Vol. 21, No. 4, Oktober 2017: 562-574

tive impact of institutional ownership indicates that existence of institutional investors leading to reduced dividend payouts. It means the function of institutional ownership to control the company, especially related to dividend policy is still weak, different with Allen, Bernardo \& Welch (2000), they argue that existence of institutional investors believed are able to gave the signals that the quality of the company good and or efficient (Bichara, 2008). Institutional ownership has not been able to influence the company's management decisions to accommodate their interests. This research contrary with research conducted by Kumar (2006), Mehrani, Moradi, \& Eskandar (2011), Triwulan \& Wahidahwati (2012), and Saif et al. (2013), they found that institutional ownership has a positive and significant effect on the dividend policy.

Company profitability determines firm decision to distribute dividend. Mature and profitable companies tend to pay dividend. Chhatoi (2015) also mention that dividend policy is highly affected by company profitability. Research result indicates that profitability has a negative effect to the dividend policy. The negative effect of profitability toward dividend policy show that firm with higher profitability will pay fewer dividend compare to firms with lower profitability, otherwise, and low levels. Corporate profits will increase the company decision in paid dividend to the shareholders Companies tend to use most of the profits earned for expansion of firm and other necessities. So that profit distributed to the shareholders as dividend are smaller. This condition different with agency cost and signaling model that mention large companies with a large profit level without having a good investment opportunities tend to pay higher dividends to reduce agency problem and give positive signal to the investor. This research finding contradictory with Lintner (1956) statement that the company's profitability is the determining factor firm decision to paid dividend (Stacescu, 2006). Afza \& Mirza (2010), Trang (2012), and Biza-Khupe \& Themba (2016) found that profitability is positively related to dividend policy.

Systematic risk information is useful for investors to analyze the nature of risk related with investment. Generally, found that companies with a higher level of systematic risk tend to pay lower dividends than the companies with a lower level of systematic risk. This study shows that systematic risk has no effect to the company's dividend policy. This finding indicates that systematic risk not a determinant of corporate dividend policy. The company's decision to increase or decrease dividend payments does not influence by change in systematic risk faced by the company. This research contrary with statement by Logue \& Mervile (1972), high dividend payout give negative impact on the systematic risk due to investors feel more sureness inflow of returns from dividends as compared to higher return of stock price (Iqbal \& Shah, 2010). This finding also inverse with theory proposed by Tendelilin (2001), said that the higher of company systematic risk will be make the higher of the company's securities return sensitivity to market return change which may result lower company opportunities getting an external source of funds, so the company should be able to financing it's self through internal sources of funds, consequently, the company will increase retained earnings and reducing the amount of the dividend

Firm size indicates the big or small firm that can be expressed in total assets, sales, and market capitalization. In the way to finance firm investment projects, large companies should have preferable access to external capital markets and not relies on internal funds. Hence, large firm's able to pay more dividends compares to small firms. Research finding shows that firm's size does not affect firm dividend policy because firm size does not automatically provide certainty to investor related to company decision in paying the dividend. Generally, large firm's always presumed paid a higher dividend than smaller one by inves- 
tor, but in reality not happen in financial industry that majority of their assets owned by the public. Sometimes large firm's has more responsibility and need more financing, so they will increase retained earnings and reduce dividend distribution. Therefore dividend policy cannot be determined just by looking at the firm size.

Leverage measure how the company depends on external funds (debt level) to finance their investments. Hence leverage has inverse relationship with dividend policy. This research result shows that leverage has negative effect on the firm dividend policy. This finding in line with research conducted by Vo \& Nguyen (2014) and Ahmad \& Wardani (2015), they said there is a negative relationship between financial leverage and dividend policy. This finding is interesting, because the result indicate that when company debt level increase, and then the dividend payout will be decrease. High leverage indicates high level of financial risk and debt payment terms, have to be related with decrease dividend payments. Firms with high leverage thinking to decrease the dividend policy with the aim restricting default risk.

\section{CONCLUSION AND SUGGESTIONS}

\section{Conclusion}

The aim of this study was to indentify determinants of dividend policy by using corporate governance mechanism, profitability, systematic risk, firm size, and leverage as determinants of dividend policy, and define which of the most important variables that having powerful effect on the firm dividend policy decision. Panel data regression result shows negative relationship between institutional ownership, profitability, and leverage with firm dividend policy. Meanwhile, board of director, systematic risk, and firm size do not seem to have significant effect on the firm dividend policy in the financial industry listed in Indonesia Stock Exchange.
The relationship between institutional ownership and profitability are beyond of expectation, because contrary with theories and a number of previous researches. While leverage has relationship as expected. The contrast result also seems in the relationship between board of director, systematic risk, and firm size. Different results with a number of theories and previous researcher that show the entire variable have relationship with dividend policy. This research result can be information by investor that dividend policy in the financial industry listed in Indonesia Stock Exchange for the period of 2009-2015 affect by institutional, profitability, and leverage. There is evidence that increase in institutional ownership, profitability, and leverage will decrease dividend payment.

\section{Suggestions}

There have been several limitations of this research which may affect the research results, hence researcher suggest that long term investor who expect capital gain and dividend concern to this dividend determinant variables, especially institutional ownership, profitability, and leverage variables before making investment decision. For the company suggest paying dividend continuously, even small to preserve investor loyalty. Future research expects to use a wider research sample, not only one industry and one capital market, but more than it and longer period of time, so the number of observation is bigger and more accurate. In the way to get more determinants of dividend policy, further researcher suggests to add more independent variables by collaborate with more theories.

\section{REFERENCES}

Abdelsalam, O., El-Masry, A., \& Elsegini, S. (2008). Board composition, ownership structure, and dividend policies in an emerging market further evidence from CASE 50. Managerial Finance, 34(12), 953-964. 


\section{Jurnal Keuangan dan Perbankan | KEUANGAN}

Vol. 21, No. 4, Oktober 2017: 562-574

Abor, J., \& Fiador, V. (2013). Does corporate governance explain dividend policy in Sub-Saharan Africa? International Journal of Law and Management, 55(3), 201-225.

Adjaoud, F., \& Ben-Amar, W. (2010). Corporate governance and dividend policy: Shareholders' protection or expropriation? Journal of Business Finance $\mathcal{E}$ Accounting, 37(5-6), 648-667.

Afza, T., \& Mirza, H. H. (2010). Ownership structure and cash flows as determinants of corporate dividend policy in Pakistan. International Business Research, 3(3), 210-221.

Ahmad, G. N., \& Wardani, V. K. (2014). The effect of fundamental factor to dividend policy: Evidence in Indonesia Stock Exchange. International Journal of Business and Commerce, 4(2), 14-25.

Ahmed, I. E. (2015). Liquidity, profitability and the dividend payout policy. World Review of Business Research, 5(2), 73-85.

Aivazian, V., Booth, L., \& Clearly, S. (2003). Dividend policy and the organization of capital markets. Journal of Multinational Financial Management, 13, 101-11.

Allen, F., Bernardo, A., \& Welch, I. (2000). A theory of dividends based on tax clienteles. Journal of Finance, 55(6), 2499-2536.

Amidu, M., \& Abor, J. (2006). Determinants of dividend payout ratios in Ghana. The Journal of Risk Finance, 7(2), 136-145.

Arifin, Z. (2007). Teori keuangan dan pasar modal. $2^{\text {nd }}$ Edition. Yogyakarta: Ekonisia.

Aydin, A. D., \& Cavdar, S. C. (2015). Corporate governance and dividend policy: An empirical analysis from Borsa Istanbul Corporate Governance In$\operatorname{dex}(\mathrm{XKURY})$. Accounting and Finance Research, 4(3), 66-76.

Beabczuk, R. N. (2004). Explaining dividend policies in Argentina. Documento de Trabajo, No.50.

Belden, S., Fister, T., \& Knapp, B. (2005). Dividends and directors: Do outsiders reduce agency costs? Business and Society Review, 110(2), 171-180.

Bichara, L. Z. (2008). Institutional ownership and dividend policy: A framework based on tax clientele, information signaling, and agency costs. Disserta- tion. Doctor of Philosophy University of North Texas.

Biza-Khupe, S., \& Themba, A. (2016). The relationship between dividend payout and firm financial performance: A study of Botswana listed companies. Archives of Business Research, 4(4), 33-40.

Black, F. (1976). The dividend puzzle. Journal of Portfolio Management, 2(2), 5-8.

Brigham, E. F., \& Daves, P. R. (2004). Intermediate financial management. $8^{\text {th }}$ Edition. South-Western: Thomson.

Chang, R.P. \& Rhee, S.G. (1990). The impact of personal taxes on corporate dividend policy and capital structure decisions. Financial Management, 19(2), 21- 31 .

Cheryta, A. M., Gumanti, T. A., \& Nusbantoro, A. J. (2015). Pengaruh biaya agensi, risiko sistimatik dan peluang investasi terhadap kebijakan dividen perusahaan yang terdaftar di BEI 2009-2013. Artikel Ilmiah Mahasiswa, Universitas Jember.

Chhatoi, B. P. (2015). A study on relationship between profitability and dividend payment in Iron \& Steel Industries in India. Pacific Business Review International, 8(1), 70-78.

Coskun, M., \& Sayilir, O. (2012). Relationship between corporate governance and financial performance of Turkish companies. International Journal of Business and Social Science, 3(14), 59-64.

Denis, D. J., \& Osobov I. (2008). Why do firms pay dividends? International evidence on the determinants of dividend policy. Journal of Financial Economics, $89,62-82$.

Elmi, M. A., \& Muturi, W. M. (2016). Effects of profitability on dividend payout by commercial and services firms listed in the Nairobi securities exchange. European Journal of Business and Social Sciences, 5(2), 160-167.

Fadah, I. (2010). Faktor penentu dividen dan biaya keagenan serta pengaruhnya pada nilai perusahaan. Jurnal Keuangan dan Perbankan, 14(3), 391-406.

Fama, E. F., French, K. R. (2001). Disappearing dividends: changing firm characteristics or lower propensity to pay? Journal of Applied Corporate Finance, 14(1), $67-79$ 
Gitman, L. J. 2009. Principles of managerial finance. $12^{\text {th }}$ Edition. Boston: Pearson

Gusni. (2016). Dividend policy, corporate governance mechanism, profitability, systematic risk, and firm size: A panel data analysis. $4^{\text {th }}$ Gadjah Mada International Conference on Economics and Business.

Hidayati, N., \& Sunaryo, H. (2016). Dampak corporate governance terhadap keputusan dividen (Literature review pada negara-negara di Asia, Australia, dan Afrika). Jurnal Keuangan dan Perbankan, 20(1), 32-41.

Hutchinson, M., \& Gul, F. (2004). Investment opportunity set, corporate governance practices, and firm performance. Journal of Corporate Finance, 10(4), 595614.

Iqbal, M. J., \& Shah, S. Z. A. (2010). Determinants of systematic risk. The Journal of Commerce, 4(1), 47-56.

Jiraporn, P., Kim, Young. S., Kim, J. C. (2011). Dividend policy and corporate governance quality: Evidence from the Institutional Shareholder Services (ISS). Journal of the Financial Review, 46, 251-279.

Jogiyanto, H. (2009). Teori Portofolio dan Analisis Sekuritas. $6^{\text {th }}$ Edition. Yogyakarta: BPFE UGM.

John, K. \& Senbet, L. W. (1998). Corporate governance and board effectiveness. Journal of Banking $\mathcal{E}$ Finance, 22, 371-403

Kajola, S. O., Desu, A. A., \& Agbanike, T. F. (2015). Factors influencing dividend payout policy decisions of Nigerian listed firms. International Journal of Economics, Commerce, and Management, 3(6), 539-557.

Kania, S. L. (2005). What factors motivate the corporate dividend decision? Theses, Dissertations $\mathcal{E}$ Honors Papers, Longwood University, paper 195

Keenan, J. (2004). Corporate governance in UK/USA boardrooms. Corporate Governance: An International Review, 12, 172-176.

Kowalewski, O., Stetsyuk, I., \& Talavera, O. (2007). Does corporate governance affect dividend policy? Evidence from Poland. Warsaw School of Economics, World Economy Research Institute, Poland, 1-58.

Kulathunga, K. M. K. N. S., Weerasinghe, W. D. J. D., \& Jayarathne, J. A. B. (2017). Corporate governance and dividend policy: A study of listed manufac- turing companies in Sri Lanka. International Journal of Scientific Research and Innovative Technology, $4(2), 64-81$.

Kumar, J. (2006). Ownership structure and dividend payout policy in India. Journal of Emerging Market Finance, 5(1), 15-58.

Kouki, M., \& Guizani, M. (2009). Ownership structure and dividend policy: Evidence from the Tunisian stock market. European Journal of Scientific Research, 25(1), 42-53.

Lind, D. A., Marchal, W. G., \& Wathen, S. A. (2012). Statistical techniques in business $\mathcal{E}$ economics. $15^{\text {th }}$ Edition. New York: McGraw-Hill Irwin.

Lintner, J. (1956). Distribution of incomes of corporations among dividends, retained earnings and taxes. American Economic Review 46, 971-113.

Logue, L., \& Merville, J. (1972). Financial policy and market expectations. Financial Management, 1(3), 3744.

McClave, J. T., \& Sincich, T. L. (2013). Statistics. $12^{\text {th }}$ Edition. Boston: Pearson

Mehrani, S., Moradi, M., \& Eskandar, H. (2011). Ownership structure and dividend policy: Evidence from Iran. African Journal of Business Management, 5(17), 7516-7525.

Miller, M. H., \& Modigliani, F. (1961). Dividend policy, growth, and the valuation of shares. Journal of Business, 34, 411-433.

Moradi, M., Salehi, M., \& Honarmand, S. (2010). Factors affecting dividend policy: Empirical evidence of Iran. Poslowna Izvrsnost Zagreb, 4, 45-62.

Myers, M., \& Bacon, F. (2004). The determinants of corporate dividend policy. Academy of Accounting and Financial Studies Journal, 8(3), 17-28.

Naceur, S. B., Goaied, M., \& Belanes, A. (2006). On the determinants and dynamics of dividend policy. International Review of Finance, 6(1-2), 1-23.

Pandey, I. M. (2001). Corporate dividend policy and behavior the Malaysian experience. Working paper, No. 2001-11-01.

Pujiastuti, T. (2008). Agency cost terhadap kebijakan dividen pada perusahaan manufaktur dan jasa 


\section{Jurnal Keuangan dan Perbankan | KEUANGAN}

Vol. 21, No. 4, Oktober 2017: 562-574

yang go public di Indonesia. Jurnal Keuangan dan Perbankan, 12(2), 183-197.

Rachman, A. N., Rahayu, S. M., \& Topowijono. (2015). Pengaruh good corporate governance dan financial leverage terhadap kinerja keuangan dan nilai perusahaan (Studi pada perusahaan yang terdaftar di indeks Sri Kehati selama periode 20112014). Jurnal Administrasi Bisnis, 27(1), 1-10.

Reddy, Y. S., \& Rath, S. (2005). Disappearing dividends in emerging markets? Evidence from India. Emerging Markets Finance and trade, 41(6), 58-82.

Roy, A. (2015). Dividend policy, ownership structure, and corporate governance: An empirical analysis of Indian firms. Indian Journal of Corporate Governance, 8(1): 1-33.

Saif, N., Rehman, S., Khan, M. S., Rehman, K., Ali, A., Khan, A., \& Khan, Q. (2013). Institutional ownership and dividend per share: Case of Pakistan. International Journal of Academic Research in Accounting, Finance, and Management Sciences, 3(1), 90-104.

Shleifer, A. \& Vishny, R.W. (1997). A survey of corporate governance. Journal of Finance, 52(2), 737-783.

Short, H., Zhang, H., \& Keasey, K. (2002). The link between dividend policy and institutional ownership. Journal of Corporate Finance, 8, 105-122.

Stacescu, B. (2006). Dividend policy in Switzerland. Financial Markets and Portfolio Management, 20(2), 153-183.
Tendelilin, E. (2001). Analisa investasi dan manajemen portofolio. Yogyakarta: BPFE UGM.

Thanatawee, Y. (2014). Ownership structure and dividend policy: Evidence from China. International Journal of Economics and Finance, 6(8), 197-204.

Trang, N. T. X. (2012). Determinants of dividend policy: The case of Vietnam. International Journal of Business, Economics and Law, 1, 48-57.

Triwulan, H., \& Wahidahwati. (2012). Pengaruh struktur corporate governance dan keputusan keuangan terhadap kebijakan deviden dan nilai perusahaan. Jurnal Ilmu \& Riset Akuntansi, 1(12), 1-18.

Vo, D. H., \& Nguyen, V. T. -Y. (2014). Managerial ownership, leverage, and dividend policies: Empirical evidence from Vietnam's listed firms. International Journal of Economics and Finance, 6(5), 274-284.

Yuliani. (2013). Keputusan investasi, pendanaan, dan dividen terhadap nilai perusahaan dengan risiko bisnis sebagai variabel mediasi. Jurnal Keuangan dan Perbankan, 17(3), 362-375.

Yulianto, A. (2014). The corporate governance mechanisms towards dividend policy in Indonesian Stock Exchange. Journal of Basic and Applied Scientific Research, 4(3), 85-91.

Zhao, Y. (2013). The relationship between share price gains, corporate performance, and risk. iBusiness Journal, 5(3B), 110-112. 